\title{
The Effect of Professional Development on Indonesian EFL Teachers' Self-Efficacy
}

\author{
Bachtiar \\ Widyaiswara Dinas Pendidikan Provinsi Sulsel \\ Address: Jl. Perintis Kemerdekaan KM. 10 Makassar, Sulawesi Selatan 90245 \\ Email: greatiar@yahoo.co.nz
}

\begin{abstract}
This study aims to find out the relationship between teachers' participation in professional development (PD) and changes in perceived levels of their self-efficacy in the areas of instructional strategy, classroom management, and student engagement. A mixed methods research was used in this study. The findings from this study revealed that there is a relationship between teachers' participation in PD and changes in perceived levels of their self-efficacy. The findings also revealed that PD was perceived to bring about the greatest change in levels of all participants' self-efficacy in the area of instructional strategy compared to classroom management and student engagement. The study suggests that one of the characteristics of good quality PD for junior secondary EFL teachers in Indonesia is the content should be based on teachers' classroom practical needs.
\end{abstract}

Keywords: professional development (PD), teacher self-efficacy, EFL teachers

\section{Introduction}

There is a growing consensus that professional development (PD) is an essential mechanism for increasing teaching quality (Boyle, While, \& Boyle, 2004; Clarke \& Hollingsworth, 2002; DarlingHammond \& McLaughlin, 1995; Guskey, 2003). Effective PD is seen to be the key to the success of any education reform initiative that helps teachers improve their teaching in the classroom. Clarke and Hollingsworth (2002) suggest PDshould become a process to change teachers' knowledge, beliefs and attitudes. Change in these aspects should lead to changes in teachers' classroom practice and behaviour.

Despite the research evidence that suggests the need to promote effective PD and a growing consensus of what PD should look like, the fact is that many PD activities are still characterized by one-shot and short-term approaches, including in Indonesia (Cannon \& Arlianti, 2008; Corcoran, 1995; Hendayana, 2007; Little, 1999; Sandholtz, 2002). In the Indonesian context, although a search of the literature has been conducted on teacher PD, little research, if any, has tried to identify the 
characteristics of effective PD that EFL teachers felt had the potential to positively affect their practice.

In addition to the effect of PD on teachers' classroom practice and behaviour, researchers have also explored the effect of PD on teacher self-efficacy. Effective PD is believed to help teachers enhance their self-efficacy (Karimi, 2011; Ross \& Bruce, 2007). Enhancing teacher self-efficacy is important because it is related to actions teachers take, and/ or outcomes of actions they achieve (TschannenMoran, Hoy, \& Hoy, 1998). In addition, it has been argued that teachers' knowledge and understanding about teaching are not enough to achieve students' academic success; teachers need to have high efficacy beliefs of their own teaching capability in order to allow them to transfer their knowledge optimally to students (Bandura, Barbaranelli, Caprara, \& Pastorelli, 1996; Pajares, 1996).Research indicates that teachers with high self-efficacy tend to plan their duties better than teachers with low self-efficacy (Bandura, 1993; Tschannen-Moran \& Hoy, 2007).

However, little research has been conducted on the effect of PD on teacher self-efficacy in the areas of instructional strategy, classroom management, and student engagement. These three areas are important to discuss because they are directly related to teachers' classroom practice (Tschannen-Moran \& Hoy, 2001), and these three areas become common topics to discuss when teachers attend PD activities. The limited number of studies in this area does call for carrying out more research studies that probe the effects of meaningful PD for teachers that affect teacher efficacy, including in these three areas (Ross, 1994; Tschannen-Moran \& Hoy, 2001).This dearth of research studies is far more evident when it comes to teaching English as a foreign language (EFL), including in Indonesia. Therefore, the present study dealswith the effects of PD activities on EFL teacher self-efficacy in the areas of instructional strategy, classroom management, and student engagement.

\section{A. Teacher Self-efficacy}

Bandura's (1999) social cognitive theory provides the theoretical foundation for self-efficacy. The social cognitive theory defines "human behaviour as a triadic, dynamic, and reciprocal interaction of personal factors, behaviour, and the environment" (Stone, 1993, p. 3). This theory implies that people need to develop ability in regulating the motivational, affective and social determinants of their intellectual functioning as well as the cognitive aspects. Good self-regulators do better academically than poor selfregulators (Pajares, 1996).

One of the fundamental aspects of social cognitive theory is self-efficacy. Bandura (1997) defines self-efficacy as composed of "beliefs in one's capabilities to organize and execute the courses of action required to produce given attainments" (p. 3). He states that people can do something better when they have high efficacy beliefs about their capabilities than those who have low efficacy beliefs about their capability.

According to Bandura's (2006) theory, people develop self-efficacy beliefs by interpreting information from four sources. The four sources are: mastery experiences, verbal persuasion, vicarious experiences, and physiological states. The four sources of information are important because 
individual's beliefs are developed by cognitively processing diversesources of information(Schwartz, 2010). Of the four sources of self-efficacy above, mastery experiences are considered as the most important source of self-efficacy in relation to one's performance (Bandura, 1999; Schmidt \& Shumow, 2012). This is because a prior success in an activity is thought to build one's self-efficacy beliefs for similar tasks in the future, while repeated failures can lower one's self-efficacy perceptions(Schmidt \& Shumow, 2012).

Mastery experiences (performance experiences) refer to interactions in a specific situation(Bandura, 1999). A strong sense of efficacy is created through repeated successes. Repeated success builds strong beliefs in one's personal efficacy, whereas failures create weak efficacy beliefs (Tschannen-Moran et al., 1998). Mastery experiences are the most powerful in shaping self-efficacy because they “provide genuine evidence about the person's ability to perform in a situation" (Mongillo, 2011, p. 17). Vicarious experiencesrefer to social comparison through observing the successes and failures of others. Vicarious experiences impact people's efficacy beliefs when they observe others' behaviour and use these experiences to form their expectancies in relation to their own behaviour and its consequences (Bandura, 1997; Hansen, 2005). Verbal or social persuasion refers to specific performance feedback from colleagues, supervisors, or from other people concerned with one's ability to achieve something (Hoy, 2000). People who are persuaded verbally that they possess the capabilities to be successful most often exert greater effort and try harder. Therefore, a learner can be persuaded of thelikelihood of success for a task. Yet, if the task is not deemed successful by thelearner, it will be disregarded (Schwartz, 2010). Physiological and emotional states refer to the physical and emotional reactions of the body during an activity (Bandura, 1997).

In terms of teacher self-efficacy, its construct is generally grounded in the psychological frames of Bandura (1997, 1999). Teacher's self-efficacy has been defined as "teacher's belief in his or her capability to organize and execute courses of action required to successfully accomplish a specific teaching task in a particular context" (Tschannen-Moran et al., 1998, p. 233). Further, teacher self-efficacy has also been conceptualized as teachers' beliefs in their own ability to plan, organize and carry out activities required to attain given educational goals (Federici \& Skaalvik, 2012), or as "teachers' belief or conviction that they can influence how well students learn, even those who may be difficult or unmotivated" (Guskey $\&$ Passaro, 1994, p. 4).

Teacher self-efficacy theory that is applied in the educational context has encouraged a rich line of research (Tschannen-Moran et al., 1998). This is because teachers' self-efficacy beliefs are related to actions teachers take and/or outcomes of actions they achieve. According to Tschannen-Moran and Hoy (2001), self-efficacy for teachers is important because it determines the degree to which teachers can control their own actions internally or externally. For example, teachers who do not expectto be successful with certain students are likely put less efforts in preparing and delivering instructions, and to give up easily although they, in fact, know instructional strategies that could assist these students.

\section{6}


Previous research indicates that efficacious teachers tend to plan their duties better than low efficacy teachers (Bandura et al., 1996; Gersten, Keating, Yovanoff, \& Harniss, 2001). This is because high efficacy teachers perceive difficult tasks as challenges to be solved rather than consider them as threats to be put aside. They set challenging teaching goals and set a strong target to achieve them (Bandura, 1993; Tschannen-Moran \& Hoy, 2007). On the other hand, low efficacy teachers usually shy away from difficult tasks because they perceive these tasks as personal threats (TschannenMoran \& Hoy, 2007). Low efficacy teachers also have low commitment to the learning goals that they have stated. They tend to give up easily in handling and facing difficult conditions and find difficulties in recovering their sense of efficacy after failure or setbacks (Caprara, Barbaranelli, Steca, \& Malone, 2006). Anaphora (2005) in her research on the issues of self-efficacy of novice teachers at the beginning of their teaching career, argues that although teachers come to classrooms with good understanding of subject matter, they find difficulty in balancing their theoretical framework and practice. According to Anaphora, the stage of transition from learning to teaching requires a lot of confidence, which new teachers mostly do not possess. Providing new teachers with some PD opportunities to help lift their self-efficacy would be highly critical in their first years of teaching. Similarly, Knoblauch and Hoy (2008) state that teachers need more than content and pedagogy knowledge to allow them to be effective in teaching and gain the goals. Teachers need motivation and a sense of efficacy to be able to transfer content and pedagogy knowledge optimally.
In recent years, a few studies have been conducted to investigate the link between teacher self-efficacy and teacher teaching practice in Asian countries (Chong \& Ong, 2016; Malinen, 2016), including one study in the Indonesian context (Kamil, Mukminin, \& Kassim, 2014). Chong and Ong (2016) investigated the link between self- and collective efficacy and school academic climate on student achievement. They found that teachers with higher perceptions of self- and collective efficacy had higher beliefs to promote organizational changes and student achievement.

\section{B. Professional Development}

A growing body of research has pointed out the benefits of PD for teachers (e.g. Darling-Hammond \& McLaughlin, 1995; Desimone et al., 2002; Guskey, 2003). Diaz-Maggioli (2003) stresses the importance of PD as the way for teachers to succeed in their professional job. This is because PD focuses especially on how teachers learn new methods and skills as processes to meet their students' learning needs. Along the same lines, Ingvarson, Meiers, and Beavis (2005) see PD for teachers as a vital component of policies to enhance the quality of teaching and learning which promotes a responsible, creative, and proactive approach. Therefore, PD is seen an appropriate process to increase teacher knowledge and skills (Boyle et al., 2004; Desimone et al., 2002; Fishman, Marx, Best, \& Tal, 2003; Guskey, 2003).

According to Fishman et al. (2003), PD should be able to help teachers increase their knowledge, skills, and attitude because these aspects have a strong link to teachers' practices in the classroom. These 
ideas are supported by Feiman-Nemser (2001) who perceives PD as a process of transferring knowledge, skills, and understanding to teachers to improve their personal practice and shared responsibility.

There is an agreement among researchers that 'innovative' PD is much more effective than 'traditional'PD(Borko, 2004; Butler et al., 2004; Desimone et al., 2002).Van Veen, Zwart and Meirink(2012) provide definitions of traditional and innovative forms of PD. Traditional refers to the way PD is organized in that the PD activities are not situated in teachers' workplace, the content is not adjusted to the issues and problems in teachers' daily teaching practice, and teachers play a passive role during the PD process. Some examples of traditional forms of PD are seminars, one-day workshops, and conferences. Innovative forms refer to all those interventions in which teachers play an active role and the issues in their own teaching practice determine the content.Some examples of innovative forms are mentoring, coaching, study groups, research by teachers, and networking (Garet et al., 2001).

A growing body of research indicates that many of PD programmes are still conducted in more traditional forms and may not meet the ultimate objectives of PD namely to enhance the quality of teaching and learning (Little, 1999; Sandholtz, 2002). Some researchers indicate that many teachers attend short term PD sessions that are selected by others, presented by outside experts and predominantly led by the use of direct instruction (e.g. Sandholtz, 2002; Schlager \& Fusco, 2003). This is because PD providers assume that teachers need information from outside experts to 'fix up' inadequacies in their practice (Keown, 2009). Such PD frequently ignores key principles of adult learning (Vella, 1995), and teachers are often seen as passive recipients and the content of PD is frequently separated from teachers' daily work (Allen et al., 2005; Sandholtz, 2002).

Butler, et al., (2004) criticize traditional models of PD as failing to deepen teachers' knowledge and being insufficient to change deep rooted beliefs in practice. Teachers often find traditional models are boring and irrelevant, and claim to forget more than ninety per cent of what they learn (Allen et al., 2005; Miller, 1998). Robb (2000), for example, describes a typical one-shot workshop and noticed that after the firstfifteen minutes, "some teachers doodling, others closed their eyes and many other teachers repeatedly looked at their watches" (p. 5). Another problem with traditional approaches to $\mathrm{PD}$ is that the activities do not capitalize on the expertise of teachers, rather they operate from a deficit model (Feiman-Nemser, 2001).

On the other hand, many researchers claim that innovative forms of PD are more effective to meet teachers' needs because most of these activities are in the form of collaboration and are grounded in teachers' classroom practice (e.g. Butler et al., 2004; Desimone et al., 2002). Many researchers believe that innovative models provide greater opportunities for teachers to try new ideas, and reconstruct knowledge and skills about teaching as a prerequisite to increase teachers' knowledge and improve pedagogy (DarlingHammond \& McLaughlin, 1995; Desimone, 2009). Innovative forms of PD take into account teachers' existing frames of knowledge and experience, as well 
as a classroom practical focus. James (2001) mentions PD is effective when it exploits fully the knowledge that teachers bring with them. McGee (2011) also indicates the importance of teacher professional learning activities having a practical focus because this will enable teachers to value these activities as they are not separate from their everyday work.

\section{Professional Development for Teachers in Indonesia}

Realizing that the overall achievements of the Indonesian education system are still rather disappointing, the government of Indonesia has made tremendous efforts to improve the quality of teachers (Hendayana, Asep, \& Imansyah, 2010). One of their efforts is through PD activities. PD programs for teachers have had a strong tradition in Indonesia since the 1970s. Two-thirds of the World Bank budget for education in Indonesia during the 1980s was devoted to teacher PD initiatives (Fuller, 1987 as cited in Thair \& Treagust, 2003).

Indonesian teachers' opportunity to attend PD to improve their professionalism is guaranteed by Indonesian law (Evans et al., 2009; Hendayana, 2007). One of the current foci for teacher PD in Indonesia is lifting academic qualifications of teachers with a two or three years-diploma degree to bachelor degree. It is believed that gaining an academic professional qualification has a proportional relationship with the mastery of subject content and teaching strategies that can potentially increase successful student learning (Saito, Hendayana, Imansyah, Isamu, \& Hideharu, 2006; Tanang \& Abu, 2014). Currently, there is an increase in the numbers of teachers who hold master and doctoral degrees as a means to improve the quality of the teaching profession and for career opportunity (Hendayana et al., 2010).

PD has been implemented in Indonesia to attempt to fulfil the needs of teachers to increase their knowledge, skills, and attitude. Among PD activities are seminars, workshops, training, mentoring, coaching, and subject teacher's forum (Evans et al., 2009; Sudarminta, 2000). In Indonesia, PD programs have particularly been implemented to disseminate new curriculum policies or approaches in teaching. In many cases, the central government invites some teachers to participate in PD activities such as workshops and training as a representative for each region/district. Later, the teachers will become disseminators to their colleagues in their district/ school to spread the information, including to the rural areas (Tanang $\&$ Abu, 2014). In the Indonesian school setting, PD for teachers has increased since 2005, whilst before this time PD activities were not a priority for teachers and/or schools in Indonesian (Iwani, 2014).

\section{Methods}

This research was conducted in three districts in South Sulawesi province of Indonesia. The researcher especially selected the three districts that were "likely to be information-rich" (Gall, Gall, \& Borg, 2005, p. 310). All the three districts were purposefully selected from among a list of potential districts using predetermined criteria.

This study involved four phases of data collection. The participants for the initial questionnaires and the follow-up questionnaires consisted of the entire population of junior secondary English language 
teachers (around 168 teachers) in the three districts. For TSG observations, purposive sampling was used to identify three TSGs within the population that met the specific criteria and could be accessed. To find out more in-depth details and to triangulate the data from both the questionnaires and TSGs observations, six teachers from each of the TSGs (N $=18$ ) were interviewed.

Data Gathering Tools. The investigative tools that were utilized in this study included questionnaires, TSG observations, and semistructured interviews. These multiple sources of data provided triangulation that contributed to the trustworthiness and validity of the study (Glesne $\&$ Peshkin, 1992; Maxwell, 2012). A questionnaire is a self-report instrument useful for economically and speedily obtaining data from a large number of respondents (Brown, 2001). The six-page questionnaire used for this study was divided into three separate parts. Part A (demographic data) was used to gather teachers' demographic information, including their gender, location of school, and years of teaching experience. Part B employed a Teacher Sense of Efficacy Scale (TSES). The TSES by Tschannen-Moran and Hoy (2001) that consist of 12 items was adapted and administered for this study. In the current study, the 12 items were modified to suit the study context, namely teaching of English as a foreign language in Indonesia. Part C comprised of 10 items consisting of closed questions and openended questions.

The second investigative tool was TSG observations. According to Gebhard (1999), an observation is a non-judgemental description of events which can be analysed and given interpretation. The purpose of observations in this study context wasto observe the process in the three TSGs to allow a means of understanding what, when, and how teachers conducted the TSGs and comparing reported practice to what actually happened. This study involved non-participant observation of some TSG meetings conducted by the participants in each of the three TSGs using a loosely structured observation protocol.

In addition to questionnaires and observations, semi-structured was employed. The semi-structured interviews was conducted to allow the researcher to control the direction of the interviews and to have more opportunities to acquire extensive follow-up responses (Bogdan \& Biklen, 2003; McDonough \& McDonough, 2014). The semi-structured interviews were carried out in Bahasa Indonesia.

\section{Findings and Discussion}

Of the 104 teachers who gave responses on both questionnaires, $45(43.3 \%)$ teachers were from an urban area, and 59 (56.7\%) were from rural districts. The teacher respondents included 35 (33.7\%) males and $69(66.3 \%)$ females and they had a range of teaching experience. For analyses, the data on the participants' teaching experience were divided into three categories as shown in Table 1. 
Table 1. Range of Teaching experience

\begin{tabular}{|c|c|c|c|c|c|}
\hline \multirow[b]{2}{*}{ Teaching Experience } & \multirow[b]{2}{*}{ Gender } & \multicolumn{3}{|c|}{ Frequency } & \multirow[b]{2}{*}{ Total (\%) } \\
\hline & & Urban District & Rural District A & Rural District B & \\
\hline \multirow{2}{*}{$\begin{array}{c}\text { More than } \\
15 \text { years }\end{array}$} & Male & 7 & 5 & 6 & 17.3 \\
\hline & Female & 11 & 8 & 6 & 23.1 \\
\hline \multirow{2}{*}{$6-15$ years } & Male & 4 & 5 & 6 & 14.4 \\
\hline & Female & 15 & 7 & 7 & 27.9 \\
\hline \multirow{2}{*}{ Less than 6 years } & Male & 0 & 3 & 0 & 2.8 \\
\hline & Female & 8 & 2 & 4 & 14.4 \\
\hline Total & & 45 & 30 & 29 & 100 \\
\hline
\end{tabular}

Based on the results, most of the respondents who returned both the Q1 and the Q2 ${ }^{1}$ were either very experienced teachers (more than 15 years) or experienced teachers (6-15 years). There were 17 novice teachers who took part in this study.

In order to investigate if there was a difference between the perceived level of teachers' self-efficacy at the beginning and end of the research, the total scores for each of the 104 participants were calculated for both the Q1 and the Q2. These individual scores were then used to calculate a participant's 'gain score' $\left(G S^{2}\right)$ representing how much their self-efficacy had changed over the period of the study. The means and standard deviationsof the total scores and the gain scores of the 104 teachers for the whole scales are shown in Table 2.

${ }^{1}$ Q1 (the Initial Questionnaire) \& Q2 (the Follow-up Questionnaire).

${ }^{2}$ Gain score is the difference between the initial and follow-up scores on the TSES
Table 2. Means and Standard Deviations for the cohort (104 teachers)

\begin{tabular}{|c|c|c|c|c|c|c|}
\hline \multirow{2}{*}{ Item } & \multicolumn{2}{|c|}{ The Q1 } & \multicolumn{2}{c|}{ The Q2 } & \multicolumn{2}{c|}{ GS } \\
\cline { 2 - 7 } & Means & SD & Means & SD & Means & SD \\
\hline $\begin{array}{c}104 \\
\text { teachers }\end{array}$ & $45.90^{3}$ & 3.14 & 49.19 & 3.27 & 3.29 & 1.43 \\
\hline
\end{tabular}

Table 2 shows that teachers' self-efficacy scores for all participants rose, on average, over the five months of the study from 45.90 to 49.19 , an average gain of was 3.29, 95CIs [3.01, 3.57].

\section{A. Teachers' Perception of the Importance of Self-efficacy}

The current study found that most of the participating teachers thought that good selfefficacy was important to be a successful teacher. The participating teachers reported that having high efficacy beliefs helped them to maximize their

3 Maximum score of the TSES is 60 
teaching practices, not only because it helped them to teach creatively, but it also helped them to value and utilise their skills to generate students' motivation to learn. The majority of the participants in the interview said that their perception of their ability in delivering lesson content and using certain teaching strategies determined the success of the learning process in the classrooms. The participants believed that teachers with high efficacy beliefs can maximize their successful teaching practices.

Another aspect that most of the participants perceived to be important for self-efficacy was related to choices teachers make in relation to solving teaching problems. One of them, for example, said that the level of teachers' self-beliefs about their competence influence the choices they make in solving teaching problems. High efficacy teachers will see teaching problems as challenges that need to be solved.

The participating teachers also linked selfefficacy to teachers' commitment to help students achieve learning goals. The participants, both in the questionnaires and the interviews, perceived that teachers with high self-efficacy beliefs tend to make more effort to achieve learning objectives than teachers with low self-efficacy. The findings from this study share some similarities with those of Tschannen-Moran and Hoy (2001) who indicate that teaching efficacy affords teachers the ability and feeling of confidence to make an effort when they find something does not go smoothly to achieve learning goals.

Despite the participating teachers' overall perceptions of the importance of self-efficacy as a single factor, some of them commented further that teacher self-efficacy and teacher competence are interrelated. They reported that teachers will have high efficacy beliefs when they have good knowledge and understanding about teaching. Similarly, they believed that teachers may have good knowledge and understanding about teaching but they would be unable to teach well because they have low selfefficacy. The findings from this study indicate that teachers need to have both high efficacy beliefs and good knowledge and understanding about teaching to help them to teach well. It is interesting to note, as Knoblauch and Woolfolk Hoy (2008) have also suggested, that teachers need more than content and pedagogy knowledge to allow them to be effective in teaching and achieve learning objectives. Knoblauch and Woolfolk Hoy argue that teachers need motivation and a sense of efficacy to allow them to transfer content and pedagogy knowledge optimally. The participating teachers in this study mostly reflected this view that teachers who have good knowledge and understanding about teaching tend to have high self-efficacy beliefs in their teaching.

One of the findings in this study is that the participants agreed with participants in previous studies (Lakshmanan, Heath, Perlmutter, \& Elder, 2011; Tschannen-Moran \& Hoy, 2007; Wertheim $\&$ Leyser, 2002)about the importance of having high self-efficacy, regardless of their individual differences in terms of cultural backgrounds and the content areas they taught. They shared the view that more efficacious teachers are more effective in teaching than less efficacious teachers. The findings from this study may strengthen the general agreement about the importance of self-efficacy for teachers. 


\section{B. Change on the TSES4 Sub-scales}

To investigate the difference level of teacher sense of efficacy in the areas of instructional strategies, classroom management and student engagement, an ANOVA test was conducted. The means and standard deviationsof the total scores and the gain scores on each of the sub-scales are shown in Table 3.

Table 3. Means and Standard Deviations of the Three Sub-Scales

\begin{tabular}{|l|c|c|c|c|c|c|}
\hline \multicolumn{1}{|c|}{$\begin{array}{c}\text { TSES } \\
\text { Sub-Scales }\end{array}$} & \multicolumn{2}{|c|}{ The Q1 } & \multicolumn{2}{c|}{ The Q2 } & \multicolumn{2}{c|}{ GS } \\
\cline { 2 - 7 } & Means & SD & Means & SD & Means & SD \\
\hline $\begin{array}{l}\text { Instructional } \\
\text { Strategy }\end{array}$ & 15.09 & 1.22 & 16.42 & 1.24 & 1.34 & 0.96 \\
\hline $\begin{array}{l}\text { Classroom } \\
\text { Management }\end{array}$ & 15.57 & 1.27 & 16.58 & 1.22 & 1.01 & 0.90 \\
\hline $\begin{array}{l}\text { Student } \\
\text { Engagement }\end{array}$ & 15.14 & 1.27 & 16.09 & 1.33 & 0.95 & 0.89 \\
\hline
\end{tabular}

Table 4. Output from Post Hoc Tests of the gain scores for the Three Sub-scales

Dependent Variable: TSES Sub-scale

Multiple Comparisons

Tukey HSD

\begin{tabular}{|c|c|c|c|c|c|c|}
\hline \multirow[t]{2}{*}{ (I) Subscale } & \multirow[t]{2}{*}{ (J) Subscale } & \multirow{2}{*}{$\begin{array}{l}\text { Mean } \\
\text { Differ- } \\
\text { ence } \\
(I-J)\end{array}$} & \multirow[t]{2}{*}{$\begin{array}{l}\text { Std. } \\
\text { Error }\end{array}$} & \multirow[t]{2}{*}{ Sig. } & \multicolumn{2}{|c|}{$\begin{array}{l}\text { 95\% Confidence } \\
\text { Interval }\end{array}$} \\
\hline & & & & & $\begin{array}{l}\text { Lower } \\
\text { Bound }\end{array}$ & $\begin{array}{l}\text { Upper } \\
\text { Bound }\end{array}$ \\
\hline \multirow{2}{*}{ Instructional Strategy } & Classroom Management & $.327^{\star}$ & .127 & .029 & .03 & .63 \\
\hline & Student Engagement & $.394^{*}$ & 127 & .006 & .09 & .69 \\
\hline \multirow{2}{*}{ Classroom Management } & Instructional Strategy & $-.327^{\star}$ & .127 & .029 & -.63 & -.03 \\
\hline & Student Engagement & .067 & .127 & .857 & -.23 & .37 \\
\hline \multirow{2}{*}{ Student Engagement } & Instructional Strategy & $-.394^{*}$ & .127 & .006 & -.69 & -.09 \\
\hline & Classroom Management & -.067 & .127 & .857 & -.37 & .23 \\
\hline
\end{tabular}

*. The mean difference is significant at the 0.05 level.

${ }^{2}$ Teacher Sense of Efficacy Scale
An ANOVA test of the participants'Q1 found that there was a statistically significant difference between the initial average scores of self-efficacy in the three subscales, $F(2,309)=4.57, p=.011$. The results from the ANOVA test of the gain scores identified that there was a statistically significant subgroups, $F(2,309)=5.50, p=.004$. Similarly, the result from the ANOVA test of the participants Q2 also found that there was a statistically significant difference between the final average scores of selfefficacy in the three subscales, $\mathrm{F}(2,309)=4.10$, $\mathrm{p}$ $=.017$.

A multiple comparison (Post Hoc tests) was applied to further examine which sub-scale meangain scores differed significantly from each other. The results from the multiple tests are shown in Table 4. difference in the average gain scores between the three 
Post hoc comparison using the Tukey HSD test indicated that the average gain score for instructional strategy was statistically higher than the average gain scores for classroom management and student engagement with the significant values 0.029 and 0.006 respectively $(\mathrm{p}<0.05)$ (as highlighted). However, there is no difference in the average gain score between classroom management and student engagement subscales $(p=0.857)$.

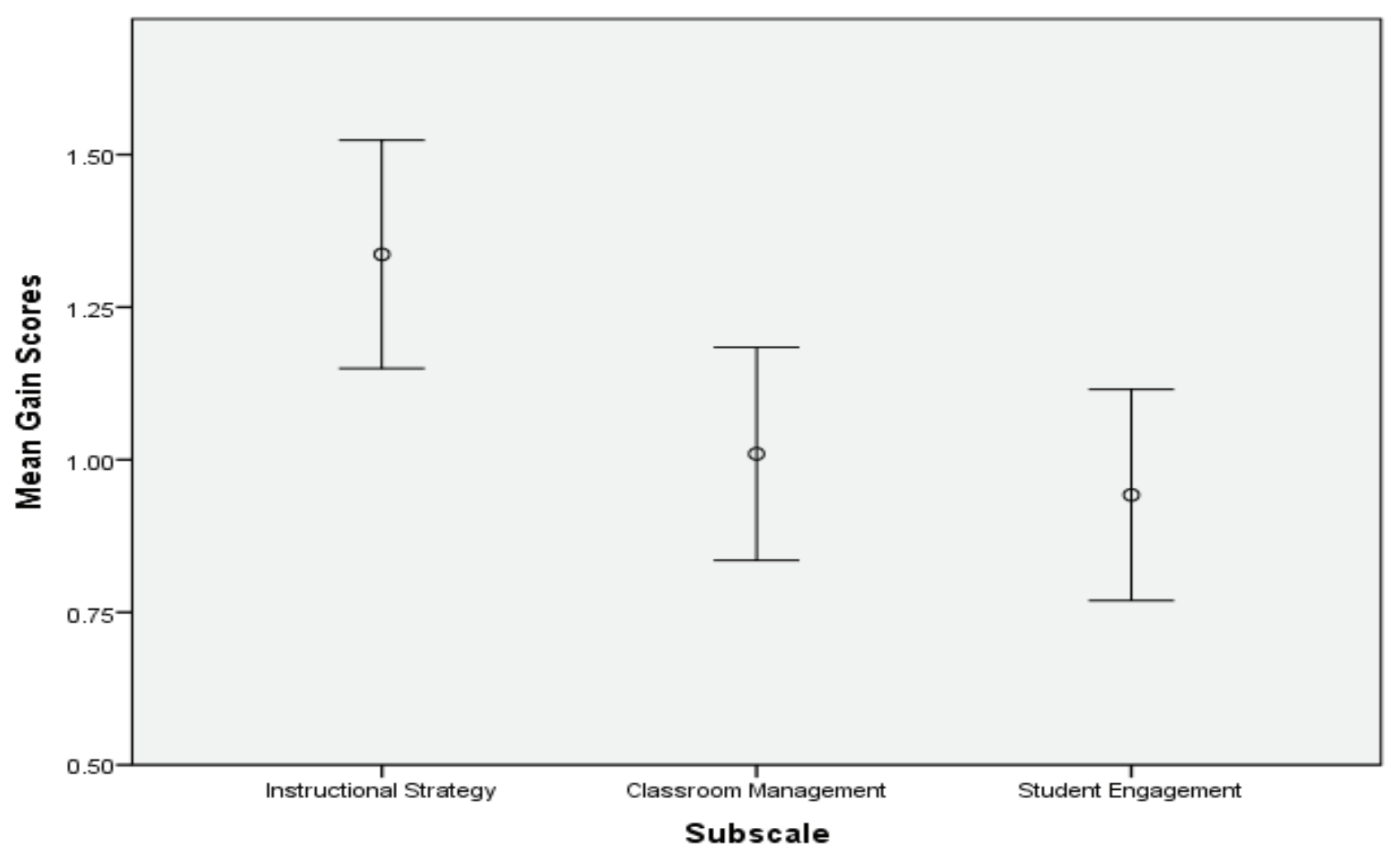

Error Bars: $95 \% \mathrm{Cl}$

Figure 1. 95\% confidence intervals for the sub-scales mean gain scores. 
The results from the calculation of the $95 \%$ confidence intervals indicate positive gain scores in all three subscales.

Findings from this study showed that over the course of the study, PD was perceived to bring about the greatest change in levels of all participants' selfefficacy in the area of instructional strategy. This finding concurs with the study by Murshidi, Konting, Elias, and Fooi (2006). However, this finding is in contrast to the study by Ross and Bruce(2007) where PD affected the greatest change in classroom management. The study by Ross and Bruce found that only the changes in classroom management were statistically significant. Ross and Bruce suspected that teachers' confidence in their ability to engage student interest and to use new instructional strategies follows confidence in classroom management. In contrast to Ross and Bruce's argument, some of the participating teachers in the interviews in this study reported that their ability to use appropriate instructional strategies affected their beliefs about engaging students and managing classrooms, and so instructional strategies were perceived to be more important.

The sort of knowledge about instructional strategies that the participants discussed when attending PD, perhaps caused them to make the greatest change in instructional strategy in this study. This assumption is consistent with many teachers' comments, where the participating teachers reported that they had learned how to deliver certain lesson content from seminars, workshops, training and TSGs. This assumption is also strengthened by the participating teachers' comments that they usually discussed and shared more information, knowledge and skills about instructional strategy in the TSGs than about classroom management and student engagement.

Another reason why EFL teachers in this study may have made the greatest changes in self-efficacy about instructional strategy could be because the English curriculum in Indonesia underwent some changes and the participants at the time of the research were focused on how to teach English lessons through appropriate instructional strategies. This seems to indicate why EFL teachers made the greatest change in their beliefs and efficacy about instructional strategy. There is an indication that the participating teachers in this study made the greatest change in the area that they were most familiar with and had experienced some success in performing, which is instructional strategy.

Although not the largest gain in self-efficacy, the participating teachers also highlighted the importance of having a good understanding of classroom management and student engagement, in addition to instructional strategy. The participating teachers reported the importanceof teachers having good knowledge and skills in all the three aspects because they thought these three aspects had a direct link to their self-efficacy and their teaching practices. The participants reported that a thorough understanding of these three aspects was necessary to effectively deliver lessons using appropriate instructional strategies, managing their classroom and engaging students to study. These perceptions are consistent with previous studies (Lloyd, 1995; Peterson et al., 2011) that found that sufficient knowledge in these three aspects was necessary in 
order to help teachers to build a good relationship and rapport with students, as well as to help teachers increase students' learning achievement.

The current study also showed that the participants had different perceived levels of efficacy beliefs across the areas of instructional strategy, classroom management and student engagement at the beginning of this study. The highest self-efficacy was in instructional strategy, followed by classroom management and student engagement. The findings from this study support Bandura's(1999)idea that self-efficacy is specific to a particular task, therefore teachers may not feel competent at all tasks. Teachers' efficacy beliefs differing across a subject domain also concurs with previous research such as Tschannen-Moran, Hoyand Hoy (1998) and Hansen (2005) who claim that teachers cannot be expected to be consistently efficacious across all teaching competencies because it is context-specific. Tschannen-Moran, Hoyand Hoy(1998), who studied beginning teachers' efficacy beliefs, found that beginning teachers did not feel efficacious in all teaching domains. A beginning teacher might have high teacher efficacy in one domain - such as classroom control - but low efficacy in another domain - such as teaching strategy. Therefore, Bandura (1997) proposed that self-efficacy beliefs are context-specific rather than ageneralized expectancy.

The findings that showed that EFL teachers' efficacy beliefs differed across the three areas at the beginning of the research are in line with the previous studies (Bandura, 1997; Valentine, DuBois, \& Cooper, 2004). However, the study by Bandura (1997) and Valentine et al. (2004) only investigated the perceived level of teacher self-efficacy without investigating changes to teacher self-efficacy as a result of participating in PD activities. The current study investigated changes in teacher self-efficacy, including the three areas (instructional strategy, classroom management, and student engagement), as a result of participating in PD. This is important to get an understanding of the effect of PD activities on teachers' knowledge and skills, and the relationship between these activites and changes on teacher selfefficacy beliefs.

In addition, the findings identified from this study about the different changes in teacher selfefficacy in these three areas, also provide some clarification of the areas in which these EFL teachers gained the most self-efficacy. These findings are important for policy makers and PD providers to take into account when considering what to include in professional activities for EFL teachers.

\section{Conclusion}

High efficacy teachers tend to plan their duties better than low efficacy teachers (Bandura et al., 1996; Stempien \& Loeb, 2002). Teachers with high efficacy are more widely to be effective in classrooms and they also appear to be the most receptive to the implementation of new instructional practices like those associated with mastery learning (TschannenMoran and Hoy, 2007). PD also affects teacher selfefficacy concerning instructional strategy, classroom management, and student engagement. The findings from the current study revealed that the greatest change in levels of all participants' self-efficacy was in the area of instructional strategy. The findings suggest that the area in which these teachers made 
the greatest change in self-efficacy was related to the area in which they experienced repeated successes the most. The findings also showed the TSES was a suitable measure to identify the effect of PD on the perceived levels and changes in teacher self-efficacy because the TSES covers a wide range of teachers' classroom activities (Bandura, 1999; TschannenMoran and Hoy, 2007).

Although this study tried to invite all junior secondary EFL teachers in three districts in the target areas and had a high response rate, the findings do not represent the entire population ofjunior secondary EFL teachers in South Sulawesi province of Indonesia or of course in Indonesia. More research using larger samples sizes, different groups, and various settings, however, needed to comprehensively investigate theeffect of PD on teacher self-efficacy, including in the areas of instructional strategy, classroom management, and student engagement. Thus, research intended to reveal the effect of effective PD interventionswhich have the potential to enhance teacher self-efficacy, including in the areas of instructional strategy, classroom management, and student engagement is called for.

\section{References}

Allen, L. E., Osthoff, E., White, P., \& Swanson, J. (2005). A ddelicate bbalance: District ppolicies and cclassroom ppractice. Chicago: Cross City Campaign for Urban School Reform.

Atay, D. (2007). Beginning teacher efficacy and the practicum in an EFL context. Teacher Development, 11(2), 203-219.

Bandura, A. (1993). Perceived self-efficacy in cognitive development and functioning. Educational psychologist, 28(2), 117-148.
Bandura, A. (1997). Self-efficacy: The exercise of control. New York: Freeman.

Bandura, A. (1999). Self-efficacy: Toward a unifying theory of behavioral change. Psychological Review, 84(2), 191-215.

Bandura, A. (2011). A social cognitive perspective on positive psychology. Revista de Psicología Social, 26(1), 7-20.

Bandura, A., Barbaranelli, C., Caprara, G. V., \& Pastorelli, C. (1996). Multifaceted impact of self囚efficacy beliefs on academic functioning. Child Development, 67(3), 1206-1222.

Bogdan, R., \& Biklen, S. K. (2003). Qualitative research for education: An introduction to theories and methods. Boston: Allyn \& Bacon.

Borko, H. (2004). Professional development and teacher learning: Mapping the terrain. Educational Researcher, 33(8), 3-15.

Boyle, B., While, D., \& Boyle, T. (2004). A longitudinal study of teacher change: What makes professional development effective? Curriculum Journal, 15(1), 45-68.

Brouwers, A., \&Tomic, W. (1999). Teacher burnout, perceived self-efficacy in classroom management, and student disruptive behaviour in secondary education. Curriculum and Teaching, 14(2), 7-26.

Brown, J. D. (2001). Using surveys in language programs. Hawaii: Cambridge Univ Press.

Cannon, R., \& Arlianti, R. (2008). Review of education development models: Lessons from models and strategies for increasing access to quality basic education in Indonesia. Journal of Development Effectiveness, 3(3), 371 - 388.

Chacón, C. T. (2005). Teachers' perceived efficacy among English as a foreign language teachers in middle schools in Venezuela. Teaching and Teacher Education, 21(3), 257-272.

Chapman, E. (2003). Assessing student engagement rates. Retrieved May 2015 from www.ericdigests. org/2005-2/engagement.html. 
Chong, W. H., \& Ong, M. Y. (2016). The mediating role of collective teacherefficacy beliefs in the relationship between school climate and teacher self-efficacy across mainstream and special needs schools. In S. Garvis\& D. Pandergast (Eds.), AsiaPacific perspectives on teacherself-efficacy (pp. 19-35). Rotterdam, The Netherlands: Sense Publisher

Clarke, D., \& Hollingsworth, H. (2002). Elaborating a model of teacher professional growth. Teaching and Teacher Education, 18(8), 947-967.

Deemer, S. A. (2004). Classroom goalorientation in highschoolclassrooms: Revealing links between teacherbeliefs and classroomenvironments. Educational Research, 46(1), 73-90.

Desimone, L. M. (2009). Improving impact studies of teachers' professional development: Toward better conceptualizations and measures. Educational Researcher, 38(3), 181-199.

Diaz-Maggioli, G. H. (2003). Professional development for language teachers. Eric Digest, 3(3), 1-4.

Dibapile, W. T. S. (2012). A review of literature on teacher efficacy and classroom management. Journal of College Teaching \& Learning, 9(2), 79-91.

Eslami, Z. R., \&Fatahi, A. (2008). Teachers' sense of self-efficacy, Englishproficiency, and instructionalstrategies: A study of nonnative EFL teachers in Iran. TESL-EJ, 11(4), 1-19.

Evans, D., Tate, S., Navarro, R., \& Nicolls, M. (2009). Teacher education and professionaldevelopment in Indonesia: A gapanalysis. Jakarta, Indonesia: Aguirre Division of JBS International, Inc.

Federici, R., \& Skaalvik, E. (2012). Teacher and principal self-efficacy: Relations with autonomy and emotional exhaustion. Science Educational Research Journal, 3(2), 125-150.

Field, A. (2009). Discovering statistics using SPSS : (and sex and drugs and rock ' $n$ ' roll) (3rd ed.). Los Angeles ; London: SAGE Publications Ltd.

Feiman-Nemser, S. (2001). From preparation to practice: Designing a continuum to strengthen and sustain teaching. The Teachers College Record, 103(6), 10131055 .
Fishman, B. J., Marx, R. W., Best, S., \& Tal, R. T. (2003). Linking teacher and student learning to improve professional development in systemic reform. Teaching and Teacher Education, 19(6), 643-658.

Gall, J. P., Gall, M. D., \& Borg, W. R. (2005). Applying educational research: A practical guide. New York, NY: Longman Publishing Group.

Garet, M. S., Porter, A. C., Desimone, L., Birman, B. F., \& Yoon, K. S. (2001). What makes professional development effective? Results from a national sample of teachers. American Educational Research Journal, 38(4), 915-945.

Gersten, R., Keating, T., Yovanoff, P., \& Harniss, M. K. (2001). Working in special education: Factors that enhance special educators' intent to stay. Exceptional Children, 67(4), 549-567.

Glesne, C., \& Peshkin, A. (1992). Becoming qualitative researchers: An introduction. New York, NY: Longman White Plains.

Gist, M. E., \& Mitchell, T. R. (1992). Self-efficacy: A theoretical analysis of its determinants and malleability. Academy of Management Review, 17(2), 183-211.

Guskey, T. R. (2003). Professional development that works: What makes professional development effective?Phi Delta Kappan, 84(10), 748-750.

Guskey, T. R., \&Passaro, P. D. (1994). Teacher efficacy: A study of construct dimensions. American Educational Research Journal, 31(3), 627-643.

Hendayana, S. (2007). Development of INSET model for improving teacher professionalism in Indonesia. NUE Journal of International Educational Cooperation Volume, 2(2), 97-106.

Hendayana, S., Asep, S., \& Imansyah, H. (2010). Indonesia's issues and challenges on quality improvement of mathematics and science education. Journal of International Cooperation in Education, $4(2), 41-51$.

Ingvarson, L., Meiers, M., \& Beavis, A. (2005). Factors affecting the impact of professional development programs on teachers' knowledge, practice, student 
outcomes \& efficacy. Professional Development for Teachers and School Leaders, 13(10), 1-28.

Iwani, A. (2014). Indonesian Christian teachers' perceptions of the effectiveness of professional development programs. (Master thesis, Columbia International University, Columbia). Retrieved from https://eric. ed.gov/?id=ED564921.

James, P. (2001). Teachers in action: Tasks for in-service language teacher education and development. London: Cambridge University Press.

Kamil, D., Mukminin, A., \& Kassim, N. L. A. (2014). From education policy to class practices: Indonesian secondary EFL teachers' self-efficacy in developing school-based EFL syllabi. Excellence in Higher Education, 4(2), 86-107.

Karimi, M. (2011). The effects of professional development initiatives on EFL teachers' degree of self efficacy. Australian Journal of Teacher Education, 36(6), 50-62.

Knoblauch, D., \& Hoy, A. W. (2008). Maybe I can teach those kids: The influence of contextual factors on student teachers' efficacy beliefs. Teaching and Teacher Education, 24(1), 166-179.

Lakshmanan, A., Heath, B. P., Perlmutter, A., \& Elder, M. (2011). The impact of science content and professional learning communities on science teaching efficacy and standards囚based instruction. Journal of Research in Science Teaching, 48(5), 534551.

Little, J. W. (1999). Teachers' professional development in the context of high school reform: Findings from a three year study of restructuring schools. ERIC Database, 45(29), 1-47.

Lloyd, S. R. (1995). Teacher traits students find helpful or bothersome: Implications for the inclusive classroom. ERIC Database, 386(304), 1-9.

Lockwood, A. (1999). The promise and potential of professional development. Journal of Educational Psychology, 18(7), 17-26.

Malinen, O.-P. (2016). Teacher efficacy research in mainland China. In S. Garvis\& D. Pendergast (Eds.),
Asia-Pacific perspectives on teacher self-efficacy (pp. 115-126). Rotterdam, The Netherlands: Springer.

Maxwell, J. A. (2012). Qualitative research design: An interactive approach. New York, NY: SAGE Publication Inc.

McDonough, J., \& McDonough, S. (2014). Research methods for English language teachers. London, United Kingdom: Routledge.

McGee, A. (2011). Building collaborative professional learning within an organisation. In J. Higgins, R. Parsons, \& L. Bonne (Eds.), Processes of inquiry: Inservice teacher educators research their practice (pp. 45-62). Rotterdam: SensePublishers.

Miller, E. (1998). The old model of staff development survives in a world where everything else has changed. Journal of Professional Development, 11(2), 45-57.

Mongillo, M. B. (2011). Exploring the development of novice teachers' self-efficacy. (Doctoral dissertation, Southern Connecticut State University, USA). Retrieved from http://search.proquest.com/ docview/902585583.

Murshidi, R., Konting, M. M., Elias, H., \&Fooi, F. S. (2006). Sense of efficacy among beginning teachers in Sarawak. Teaching Education, 17(3), 265-275.

Onafowora, L. L. (2005). Teacher efficacyissues in the practice of noviceteachers. Educational Research Quarterly, 28(4), 34-43.

Pajares, F. (1996). Self-efficacy beliefs in academic settings. Review of Educational Research, 66(4), 543578.

Pressley, M., \& Allington, R. L. (2014). Reading instruction that works: The case for balanced teaching. New York, NY: The Guilford Publications.

Robb, L. (2000). Redefining staff development: A collaborativemodel for teachers and administrators. Canada: Pearson Education Press.

Ross, J. A. (1994). Beliefs that make a difference: The origins and impacts of teacher efficacy. ERIC Database, 379(35), 1-45. 
Ross, J. A. (1998). The antecedents and consequences of teacher efficacy. Advances in Research on Teaching, $7(2), 49-74$.

Ross, J. A., \& Bruce, C. (2007). Professional development effects on teacher efficacy: Results of randomized field trial. The Journal of Educational Research, 101(1), 50-60.

Sandholtz, J. H. (2002). In-service training or professional development: Contrasting opportunities in a school/university partnership. Teaching and Teacher Education, 18(7), 815-830.

Schlager, M. S., \& Fusco, J. (2003). Teacher professional development, technology, and communities of practice: Are we putting the cart before the horse? The InformationSociety, 19(3), 203-220.

Schmidt, J. A., \&Shumow, L. (2012). Change in selfefficacy in high school science classrooms: An analysis by gender. In S. L. Britner (Ed.), Self-efficacy in school and communitysettings (pp. 53-73). New York, NY: Nova Science Publishers.

Stone, D. (1993). Social cognitive theory. Florida: University of South Florida Press.

Sudarminta, J. (2000). Tantangan dan permasalahan pendidikan di Indonesia memasuki milenium ketiga. Yogyakarta, Indonesia: Kanisius.

Swars, S. L. (2005). Examining perceptions of mathematics teaching effectiveness among elementary preservice teachers with differing levels of mathematics teacher efficacy. Journal of Instructional Psychology, 32(2), 126-139.

Tanang, H., \& Abu, B. (2014). Teacher professionalism and professional development practices in South Sulawesi, Indonesia. Journal of Curriculum and Teaching, 3(2), 10-25.

Thair, M., \& Treagust, D. F. (2003). A brief history of a science teacher professional development initiative in Indonesia and the implications for centralised teacher development. International Journal of Educational Development, 23(2), 201-213.

Tschannen-Moran, M., \& Hoy, A. W. (2001). Teacher efficacy: Capturing an elusive construct. Teaching and Teacher Education, 17(7), 783-805.
Tschannen-Moran, M., \& Hoy, A. W. (2007). The differential antecedents of self-efficacy beliefs of novice and experienced teachers. Teaching and Teacher Education, 23(6), 944-956.

Tschannen-Moran, M., Hoy, A. W., \& Hoy, W. K. (1998). Teacher efficacy: Its meaning and measure. Review of EducationalResearch, 68(2), 202-248.

Valentine, J. C., DuBois, D. L., \& Cooper, H. (2004). The relation between self-beliefs and academic achievement: A meta-analytic review. Educational Psychologist, 39(2), 111-133.

Van Der Stuyf, R. R. (2002). Scaffolding as a teaching strategy. Adolescent Learning and Development, 52(3), $5-18$.

Van Veen, K., Zwart, R., \&Meirink, J. (2012). What makes teacher professional development effective? A literature review. In M. Kooy\& K. V. Veen (Eds.), Teacher learning that matters: International perspectives (pp. 3-21). New York, NY: Routledge.

Vella, J. (1995). Training through dialogue. Promoting effectivelearning and change with adults. The JosseyBass higher and adulteducationseries. San Francisco, CA: Jossey-Bass.

Yin. (2009). Case study research: Design and methods(Vol. 5). London, United Kingdom: SAGE Publications Inc.

Zimmerman, B. J., \& Martinez-Pons, M. (1992). Perceptions of efficacy and strategy use in the selfregulation of learning. In D. H. Schunk\& J. L. Meece (Eds.), Student Perceptions in the Classroom (pp. 185-207). New York, NY: Rotledge. 